\title{
Variations in Stem Borer Infestation and Damage in Three Maize (Zea mays L.) Types in Southern Guinea Savanna and Rainforest Zones of Nigeria
}

\author{
Edache Ernest Ekoja ${ }^{1, *}$, Olufemi Richard Pitan ${ }^{2}$, Folashade Temitope Olaosebikan ${ }^{2}$ \\ ${ }^{1}$ Department of Crop and Environmental Protection, University of Agriculture, Makurdi, Nigeria \\ ${ }^{2}$ Department of Crop Protection, Federal University of Agriculture, Abeokuta, Nigeria
}

Email address:

ernestekoja@yahoo.com (E. E. Ekoja)

To cite this article:

Edache Ernest Ekoja, Olufemi Richard Pitan, Folashade Temitope Olaosebikan. Variations in Stem Borer Infestation and Damage in Three Maize (Zea mays L.) Types in Southern Guinea Savanna and Rainforest Zones of Nigeria. Agriculture, Forestry and Fisheries.

Vol. 4, No. 6, 2015, pp. 284-290. doi: 10.11648/j.aff.20150406.18

\begin{abstract}
The effects of location, maize types and borer control with carbofuran (Furadan $3 \mathrm{G} \circledR$ ) on the severity of maize stem borer infestation and damage was investigated in the late maize planting season of 2011. Treatments were laid out in randomized complete block design using a split-slip-plot factorial arrangement. Whole plot factor consisted of two locations (Southern Guinea Savanna and Rainforest agro-ecological zones of Nigeria), subplot factor consisted of $1.5 \mathrm{~kg}^{2}$ a.i.ha ${ }^{-1}$ and 0.0 $\mathrm{kg}$ a.i.ha ${ }^{-1}$ of carbofuran, while the sub-sub-plot factor comprised of three endosperm types of maize (flint, pop and sweet corn). Stem borer infestation (quantified by dead heart count and larval population per plant) and damage (quantified by \%lodged stem, \%bored internodes, \%bored ears, number of exit holes, number of stem borer cavities and number of damaged seeds per plant) as well as yield were compared. Results revealed that borer infestation and damage were significantly higher $(P<0.05)$ in the Rainforest compared with the Savanna. Single dose application of carbofuran $(1.5 \mathrm{~kg}$ a.i. $\left.\mathrm{ha}^{-1}\right)$ also significantly $(\mathrm{P}<0.05)$ increased grain yield in all the maize types at both locations. For all parameters, no significant $(P>0.05)$ location $\times$ carbofuran $\times$ maize type and location $\times$ maize type effect was detected. However, significant $(P<0.05)$ location $\times$ carbofuran and carbofuran $\times$ maize type interaction effects were observed. We conclude that in both agro ecologies, flint corn was more tolerant of borer attack while sweet corn was more susceptible compared to either flint or popcorn. In addition, carbofuran at $1.5 \mathrm{~kg}$ a.i.ha ${ }^{-1}$ can significantly reduce stem borer population in the three maize types.
\end{abstract}

Keywords: Borer, Flint, Pop, Sweet, Corn, Control

\section{Introduction}

Expansion in the cultivation of flint, pop and sweet endosperm types of maize in Nigeria is increasingly becoming inevitable given government's ban on continued importation of food grains. The demand for maize in Nigeria is high and it comprises high demand for it as food for the teeming human population, as feed for livestock, and as raw material for the production of some food and non-food products in agro-allied industries $[14,15]$. About $42 \%$ of the 785 million tons of maize produced worldwide annually are from the United States of America, while Africa accounts for only for $6.5 \%$ [16]. The 2011 estimated figure for maize yield in Nigeria shows a $17.5 \%$ increase in yield between 2000 and 2011 [7], yet indications are that production of maize inadequately meets demand quantitatively and qualitatively.

Insect pests are the most limiting factor to the production of maize and research efforts have shown that maize stem borers are the major insect pest of maize $[5,18,15,17]$. [19] listed 21 species considered being of economic importance; however, [18] reported that only a subset is damaging within any region/crop combination. The common species infesting maize in Nigeria include: Busseola fusca Fuller (Noctuidae), Eldana saccharina Walker (Pyralidae), Sesamia calamistis Hampson (Noctuidae), Chilo partellus Swinehoe (Cambridae) and Acigona ignefusalis Hampson (Pyralidae) $[11,22]$. Depending on the species, the larval stage may last 25-58 days and may have 6-8 instars [20]. Pupal stage normally takes 5-14 days after which adult moths emerge $[12,13$, and 19]. Maize stem borers usually pupate close to 
the tunnel exit or even partly outside the stem [28]. The larvae occupy and feed on different parts of maize whorl, leaves, stalk, tassel and ears. At the early stages of plant growth, damage to the growing point causes 'dead heart'. Borer damage also causes early leaf senescence, reduced translocation, lodging, direct damage to ears and increment in the incidence off stalk rot and ear rot diseases, sometimes resulting to significant yield losses $[25,4]$. The severity and nature of stem borer damage depend upon the borer species, the plant growth stage, the number of larvae feeding on the plant, and the plant's reaction to borer feeding [4, 17]. Yield losses caused by maize borers in Africa have been estimated to range from $10-100 \%$ [4].

Manipulating time of sowing to avoid severe borer infestation, removal of damaged cobs and stems from the field, selection of resistant varieties, biological controls with naturally occurring biotic agents are relied upon for stem borer control. However, where control failure exists or where they are pest outbreak, control with synthetic insecticides has been recommended. Carbofuran (Furadan 3G) applied at the rate of $1.5 \mathrm{~kg}$ a.i.ha ${ }^{-1}$ as well as Carbaryl (Vetox 85) applied at the rate of $0.75 \mathrm{~kg}$ a.i.ha ${ }^{-1}$ has been recommended $[6,23]$. Most of these recommendations for maize stem borer control emanated for researches with flint corn.

As regular pests of maize, the knowledge of yield-loss relationships between maize types grown in any locality and the stem borers is important in planning effective management strategies for the pest [10]. We therefore set up this experiment to assess the impact of maize types (flint, pop and sweet corn) and borer control with carbofuran on the severity of maize stem borer infestation and damage in two agro ecological zones of Nigeria.

\section{Materials and Method}

\subsection{Description of the Planting Materials and Study Areas}

Three maize types [flint (SUWAN-1-SR(DMR)), pop (Kaduna pop corn) and sweet corn (Oba Super 2] obtained from the Department of Crop Production, University of Agriculture, Makurdi were used for field experiment carried out between the month of August and November, 2011 at the Teaching and Research Farm of the University (coordinates: $\left.07^{\circ} 41^{\prime} \mathrm{N} 05^{\circ} 40^{\prime} \mathrm{E}\right)$ and Federal University of Agriculture, Abeokuta (coordinates: $07^{\circ} 15^{\prime} \mathrm{N}, 03^{\circ} 25^{\prime} \mathrm{E}$ ). The maize type varieties used are open pollinated and medium maturing. The flint corn was also resistant to Downy mildew disease of corn.

\subsection{Research Design}

The plots were laid out in randomized complete block design made up of six plots replicated four times giving a total of 24 plots in each location. The experiment was set up in split-slip-plot factorial arrangement with the whole plot factor consisting of two locations (Southern Guinea Savanna and Rainforest agro ecological zone of Nigeria), while the subplot factor consisted of $1.5 \mathrm{~kg}$ a.i.ha ${ }^{-1}$ and $0.0 \mathrm{~kg}$ a.i.ha ${ }^{-1}$ rates of carbofuran (Furadan 3G®). The sub-sub-plot factor was the three endosperm types of maize (flint, pop and sweet corn). Each plot was $5 \mathrm{~m}$ long and six rows wide. An inter row spacing of $0.75 \mathrm{~m}$ was maintained within plots while a 1 $\mathrm{m}$ alley way existed both within and between blocks. The total area of the field in each location was $736 \mathrm{~m}^{2}$. Paraquat at $3.0 \mathrm{~kg}$ a.i.ha ${ }^{-1}$ and pendimethaline at $2.5 \mathrm{~kg}$ a.i.ha ${ }^{-1}$ were applied immediately after sowing for weed control. This was supplemented with manual hoe weeding 7 weeks after planting (WAP). Four seeds per hole were sown on ridges and seedlings were thinned down to 2 plants per stand at 2 WAP to give a population density of approximately 53,333 plants ha $^{-1}$. Four weeks after planting, NPK (20:10:10) fertilizer was applied.

\subsection{Data Collection}

Sampling for stem borer damage assessment was carried out at harvest (12 WAP). Data on dead heart count, \% lodged stem, $\%$ bored stem, $\%$ bored internodes, $\%$ bore ears, mean number of exit holes per plant, mean number of damaged seeds per plant and mean number of filled cobs per plant were collected from 10 plants selected at random from plants in the four middle rows of each plots. At 4 WAP, plants showing "dead heart" symptoms (destruction of the growing point in the whorl as a result of the stem borer's feeding activities on young maize plants) were counted per plot. Furthermore, the stem of each sample was split and the number of larvae recovered was recorded. The length of borer tunnel on one half of the stem was measured and cumulated. The number of borer cavities was derived as a quotient of total tunnel length and mean length $(32 \mathrm{~mm})$ of mature larvae of B. fusca, the predominant borer species recovered in both locations. Ears from the sample of 10 plants were picked, dehusked and sorted into grain-filled and unfilled categories, thereafter; the ears were dried. Grain weight was recorded after threshing.

\subsection{Statistical Analysis}

All data in percentage were transformed to arcsine before the analysis of variance. Mean larval population per plant was analyzed as $\sqrt{x+0.5}$ before the preliminary F-test which was carried out for each parameter using GENSTAT Discovery Edition 4, [8]. Significantly different mean values were separated using least significant difference (LSD) at $5 \%$ level of probability.

\section{Results}

Busseola fusca was consistently the most abundant borer species in the three types of maize in both locations $(51.7 \%$ of total collection in flint corn, $58.3 \%$ in popcorn and $56.7 \%$ in sweet corn at Makurdi, Southern Guinea Savanna agro ecological zone and $48.3 \%, 54.2 \%$ and $50.0 \%$ of total collection in flint, pop and sweet corn respectively in the Rainforest agro ecological zone) (Figures 1 and 2). Higher populations of $B$. fusca were recovered from popcorn in both 
locations compared to the other maize types. S. calamistis was next in abundance with a higher population of the borer was recovered in the Rainforest zone compared to the Southern Guinea Savanna zone. Next in relative abundance was $E$. saccharina followed by $A$. ignefusalis and $C$. partellus. The later was not found in the Rainforest zone. In addition, $A$. ignefusalis was not encountered in flint corn in the Southern Guinea Savanna zone and in all the maize types evaluated in the Rainforest zone.

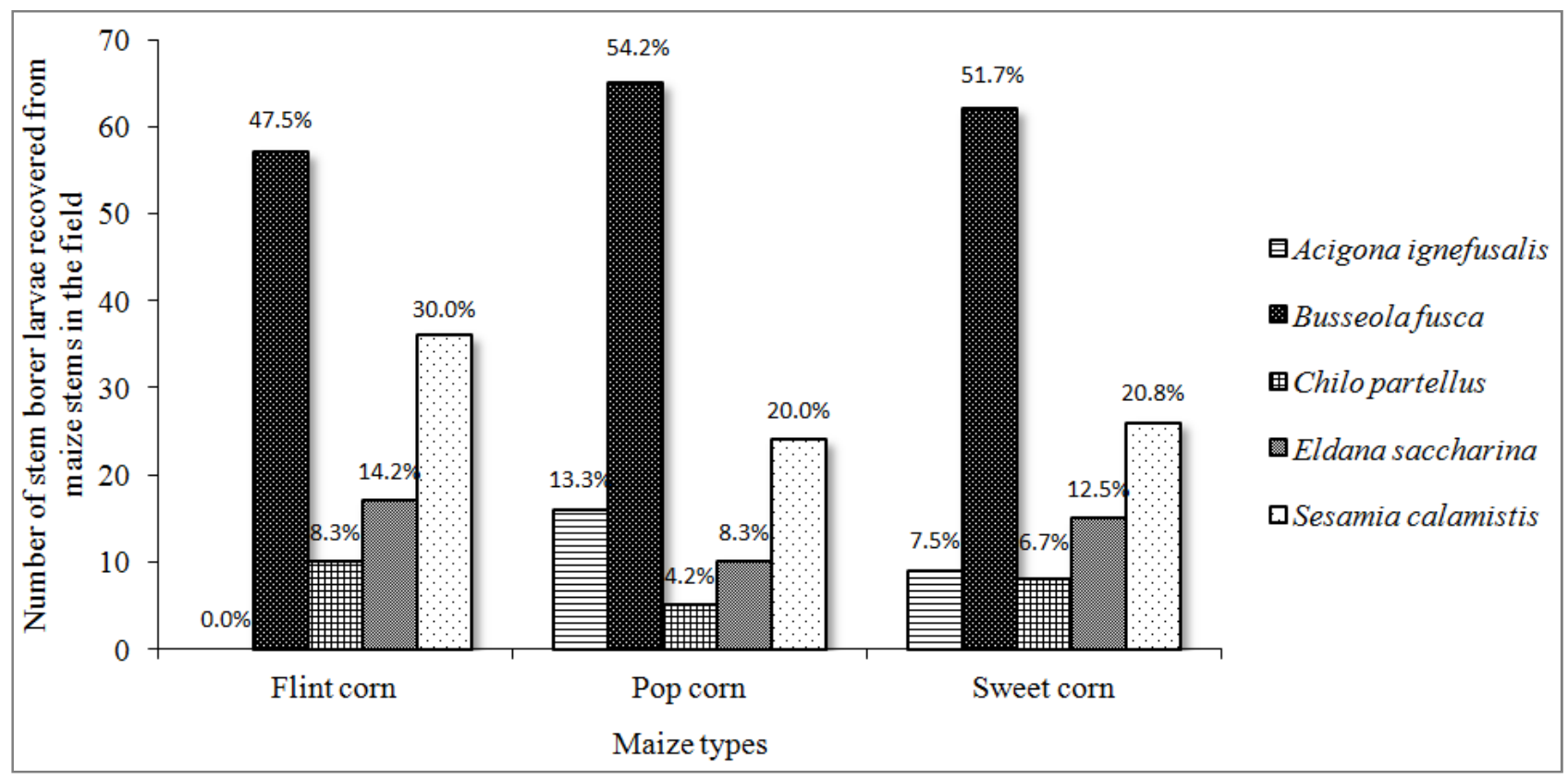

Figure 1. Species composition and relative abundance (\%) of borer recovered from the stems of maize at harvest in Makurdi, Southern Guinea Savanna agroecological zone of Nigeria. $(n=120)$.

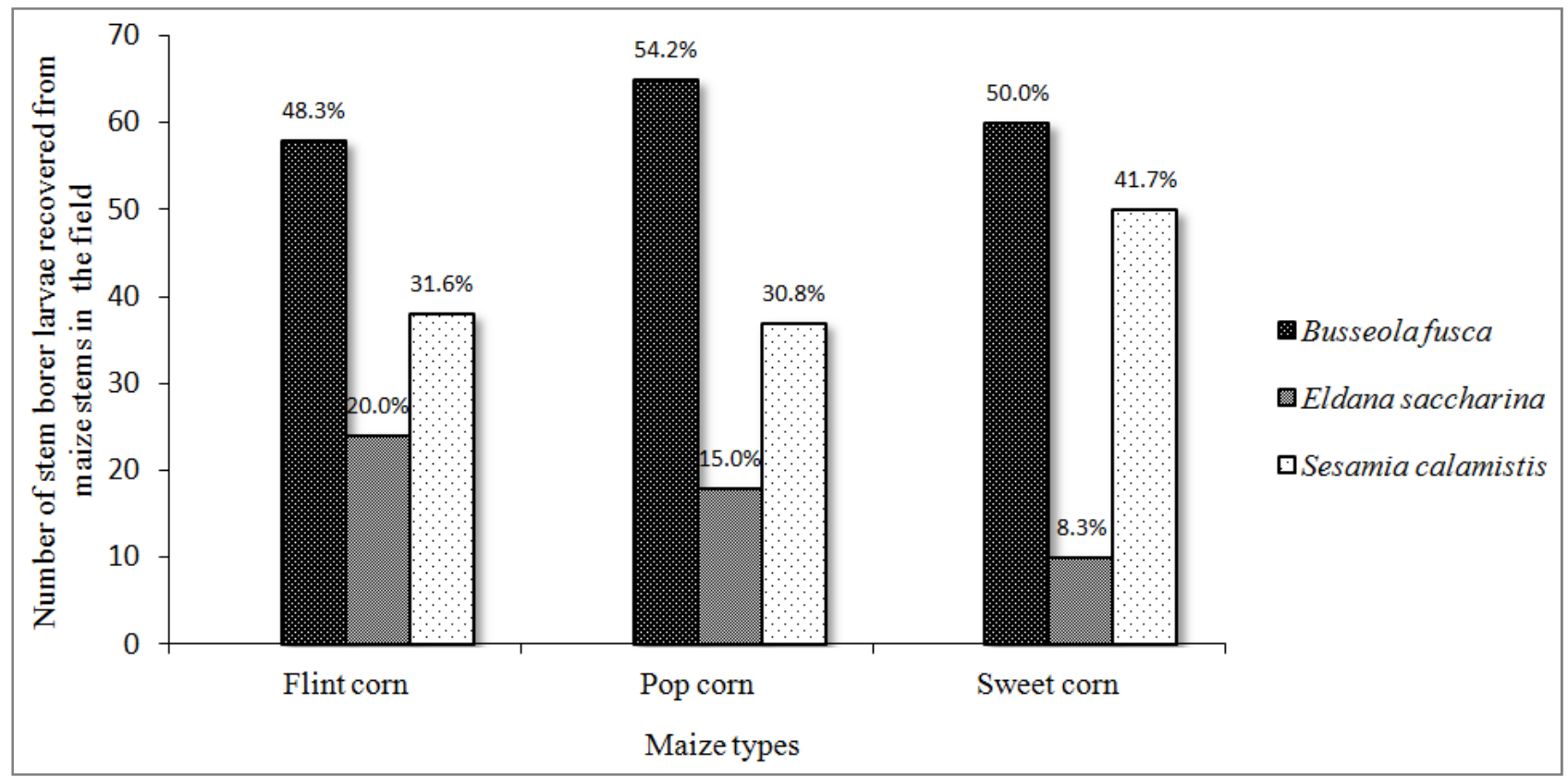

Figure 2. Species composition and relative abundance (\%) of borer recovered from the stems of maize at harvest in Abeokuta, Rainforest agro-ecological zone of Nigeria. $(n=120)$.

For all parameters, stem borer infestation and damage were significantly higher $(P<0.05)$ in the Rainforest zone compared to the Southern Guinea Savanna zone and this resulted in a significantly lower $(P<0.05)$ number of filled cobs and total grain yield of the crops grown in that environment (Table 1). Maize grain yield was about $22.8 \%$ lower in the Rainforest compared with the Savanna zone. However, the mean number of exit holes per plant and mean number of stem borer cavities per plant in both locations were not significantly different $(P>0.05)$ from each other.

Single dose soil application of carbofuran at the rate $1.5 \mathrm{~kg}$ a.i.ha ${ }^{-1}$ significantly suppressed $(P<0.05)$ borer infestation 
and damage in the three maize types in both locations (Table 1). This increased the number of filled cobs per plant and grain yield from 0.91 to 1.48 and 1.36 to 1.96 tha $^{-1}$ respectively. About $44.9 \%$ increase in grain yield was recorded from the pesticide application in all the maize types at both locations

The three maize types were susceptible to borer attacks, given the relatively high borer activities observed in them in both locations (Table 1). Apparently, sweet corn was more susceptible to the attacks given the significant $(P<0.05)$ loss of seedlings due to dead heart and other damages caused by the borer which resulted in low yield values from sweet corn plots. Marginal increase in mean larval population per plant, number of exit holes per plant and number of stem borer cavities per plant observed in sweet corn plots over pop and flint corn plots, but the differences were not significant $(P>$ $0.05)$. Flint corn was more tolerant of the borer attack, in spite of the relatively high borer activity observed in the maize type; a significantly higher yield value of 2.26 tha $^{-1}$ was obtained.

Table 1. Main effects of location and stem borer control with carbofuran on infestation, damage and yield in three endosperm types of maize (Zea mays L.).

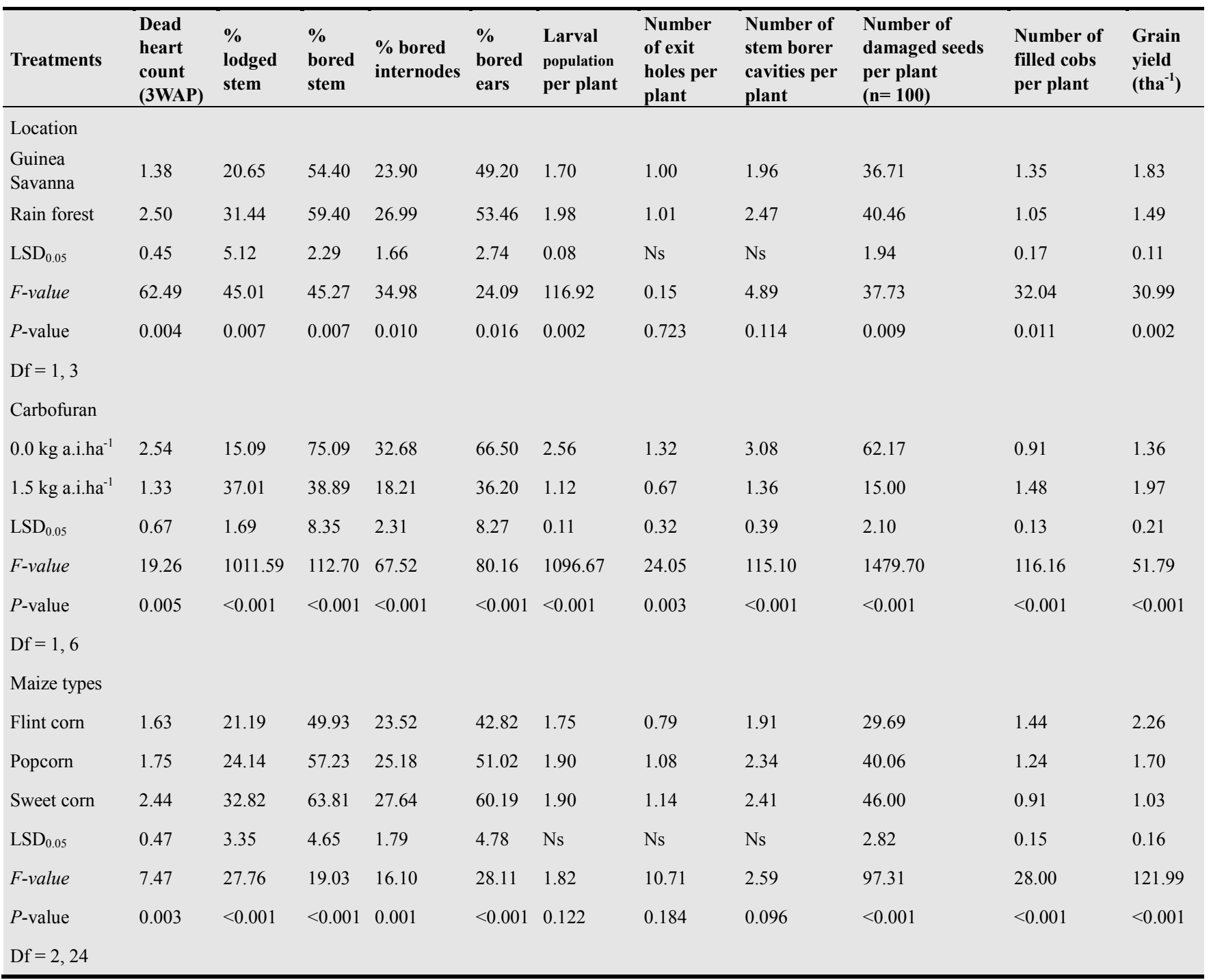

Means are values of four replicates

$\mathrm{LSD}_{0.05}=$ Fisher's Least Significant Difference at $5 \%$ level of probability

Data in percentage were transformed to arcsine values and insect count was analysed as $\sqrt{x+0.5}$ before the F-test

There was no significant $(\mathrm{P}>0.05)$ location $\times$ carbofuran $\times$ maize type and location $\times$ maize type interaction effect was detected for all parameters (Table 2). But significant $(\mathrm{P}<$ 0.05 ) location $\times$ carbofuran and carbofuran $\times$ maize type interaction effect in some parameters were observed. Percentage bored stem, mean larval population per plant and number of exit holes in carbofuran-untreated plots in the rainforest zone were significantly higher $(\mathrm{P}<0.05)$ compared with the treated plots and treated and untreated plots in the southern Guinea Savanna zone. The untreated plots of sweet corn had significantly higher $(\mathrm{P}<0.05)$ \%bored stem, \%bored ear, mean number of exit holes per plant, mean number of stem borer cavities per plant, number of damaged seeds per plant and a significantly lower $(\mathrm{P}<0.05)$ number 
of filled cobs per plant compared with the treated and untreated plots of the other maize types.

Table 2. Interactions effects of location stem borer control with carbofuran and maize types on infestation, damage and yield parameters.

\begin{tabular}{|c|c|c|c|c|c|c|c|c|c|c|c|}
\hline Treatments & $\begin{array}{l}\text { Dead } \\
\text { heart } \\
\text { count } \\
\text { (3WAP) } \\
\end{array}$ & $\begin{array}{l}\text { \% } \\
\text { lodged } \\
\text { stem }\end{array}$ & $\begin{array}{l}\% \\
\text { bored } \\
\text { stem }\end{array}$ & $\begin{array}{l}\% \\
\text { bored } \\
\text { internodes }\end{array}$ & $\begin{array}{l}\% \\
\text { bored } \\
\text { ears }\end{array}$ & $\begin{array}{l}\text { Larval } \\
\text { population } \\
\text { per plant }\end{array}$ & $\begin{array}{l}\text { Number } \\
\text { of exit } \\
\text { holes per } \\
\text { plant } \\
\end{array}$ & $\begin{array}{l}\text { Number of } \\
\text { stem borer } \\
\text { cavities per } \\
\text { plant }\end{array}$ & $\begin{array}{l}\text { Number of } \\
\text { damaged } \\
\text { seeds per } \\
\text { plant }(n=100)\end{array}$ & $\begin{array}{l}\text { Number } \\
\text { of filled } \\
\text { cobs per } \\
\text { plant } \\
\end{array}$ & $\begin{array}{l}\text { Grain } \\
\text { yield } \\
\left(\text { tha }^{-1}\right)\end{array}$ \\
\hline \multicolumn{12}{|c|}{ Location $\times$ Carbofuran } \\
\hline $\begin{array}{l}\text { Guinea Savanna } \\
\times 1.5 \mathrm{~kg} \text { a.i.ha }{ }^{-1}\end{array}$ & 0.66 & 8.26 & 37.16 & 17.64 & 35.41 & 1.04 & 0.66 & 1.09 & 13.50 & 1.70 & 2.39 \\
\hline $\begin{array}{l}\text { Guinea Savanna } \\
\times 0.0 \mathrm{~kg} \text { a.i.ha }{ }^{-1}\end{array}$ & 2.08 & 32.95 & 71.98 & 30.17 & 63.05 & 2.36 & 1.33 & 2.85 & 59.92 & 1.00 & 1.36 \\
\hline $\begin{array}{l}\text { Rain forest } \times 1.5 \\
\mathrm{~kg} \text { a.i.ha }\end{array}$ & 2.00 & 21.82 & 40.61 & 18.78 & 37.00 & 1.21 & 0.69 & 1.63 & 16.50 & 1.28 & 1.85 \\
\hline $\begin{array}{l}\text { Rain forest } \times 0.0 \\
\mathrm{~kg} \text { a.i.ha }{ }^{-1}\end{array}$ & 3.00 & 41.06 & 78.20 & 35.19 & 69.91 & 2.76 & 1.33 & 3.31 & 64.42 & 0.82 & 1.78 \\
\hline $\mathrm{LSD}_{0.05}$ & Ns & 4.80 & Ns & Ns & Ns & 0.12 & 0.32 & Ns & Ns & Ns & Ns \\
\hline$F$-value & 0.57 & 15.10 & 0.16 & 1.22 & 0.61 & 7.02 & 0.01 & 0.07 & 0.37 & 5.06 & 2.31 \\
\hline$P$-value & 0.478 & 0.008 & 0.699 & 0.312 & 0.465 & 0.038 & 0.909 & 0.801 & 0.563 & 0.066 & 0.180 \\
\hline \multicolumn{12}{|c|}{ Carbofuran $\times$ Maize types } \\
\hline $\begin{array}{l}1.5 \mathrm{~kg} \text { a.i.ha }{ }^{-1} \times \\
\text { Flint }\end{array}$ & 1.00 & 10.23 & 36.88 & 16.70 & 33.45 & 1.01 & 0.58 & 1.43 & 12.13 & 1.850 & 2.73 \\
\hline $\begin{array}{l}1.5 \mathrm{~kg} \text { a.i.ha }{ }^{-1} \times \\
\text { Pop }\end{array}$ & 1.25 & 11.52 & 39.86 & 17.88 & 36.94 & 1.18 & 0.66 & 1.34 & 16.00 & 1.54 & 2.13 \\
\hline $\begin{array}{l}1.5 \mathrm{~kg} \text { a.i.ha }{ }^{-1} \times \\
\text { Sweet }\end{array}$ & 1.75 & 23.52 & 39.92 & 20.06 & 38.24 & 1.18 & 0.77 & 1.32 & 16.88 & 1.08 & 1.51 \\
\hline $\begin{array}{l}0.0 \mathrm{~kg} \text { a.i.ha } \mathrm{h}^{-1} \times \\
\text { Flint }\end{array}$ & 2.25 & 32.15 & 62.98 & 30.34 & 52.19 & 2.48 & 0.99 & 2.39 & 47.25 & 1.03 & 1.90 \\
\hline $\begin{array}{l}0.0 \mathrm{~kg} \text { a.i.ha } \times \\
\text { Pop }\end{array}$ & 2.25 & 36.75 & 74.60 & 32.47 & 65.10 & 2.61 & 1.51 & 3.35 & 64.12 & 0.95 & 1.13 \\
\hline $\begin{array}{l}0.0 \mathrm{~kg} \text { a.i.ha } \times \\
\text { Sweet }\end{array}$ & 3.13 & 42.12 & 87.70 & 35.23 & 82.14 & 2.57 & 1.49 & 3.50 & 75.13 & 0.75 & 0.77 \\
\hline $\mathrm{LSD}_{0.05}$ & Ns & Ns & 9.21 & Ns & 9.22 & Ns & 0.35 & 0.66 & 3.81 & 0.20 & Ns \\
\hline$F$-value & 0.36 & 2.09 & 11.75 & 0.56 & 15.05 & 0.09 & 3.80 & 3.74 & 47.96 & 6.21 & 1.49 \\
\hline \multicolumn{12}{|c|}{ Location $\times$ Maize type } \\
\hline $\mathrm{LSD}_{0.05}$ & Ns & Ns & Ns & Ns & Ns & Ns & Ns & Ns & Ns & Ns & Ns \\
\hline$F$-value & 0.46 & 3.32 & 0.20 & 0.84 & 0.64 & 0.01 & 0.38 & 0.16 & 0.45 & 2.58 & 0.72 \\
\hline$P$-value & 0.638 & 0.056 & 0.816 & 0.446 & 0.534 & 0.994 & 0.964 & 0.849 & 0.642 & 0.097 & 0.495 \\
\hline \multicolumn{12}{|l|}{$\mathrm{Df}=2,24$} \\
\hline \multicolumn{12}{|c|}{ Location $\times$ Carbofuran $\times$ Maize type } \\
\hline $\mathrm{LSD}_{0.05}$ & Ns & Ns & Ns & Ns & Ns & Ns & Ns & Ns & Ns & Ns & Ns \\
\hline$F$-value & 0.05 & 1.98 & 0.12 & 2.88 & 0.19 & 0.05 & 0.03 & 0.55 & 0.17 & 1.77 & 0.61 \\
\hline$P$-value & 0.951 & 0.161 & 0.886 & 0.075 & 0.826 & 0.951 & 0.974 & 0.547 & 0.842 & 0.191 & 0.550 \\
\hline $\mathrm{Df}=2,24$ & & & & & & & & & & & \\
\hline
\end{tabular}

Means are values of four replicates

$\mathrm{LSD}_{0.05}=$ Fisher's Least Significant Difference at $5 \%$ level of probability

Data in percentage were transformed to arcsine values and insect count was analysed as $\sqrt{x+0.5}$ before the F-test.

\section{Discussion}

Population density and damage activities of stem borers observed in the study confirm previous reports which implicated the insect as a major pest of maize. The higher density of $B$. fusca in the maize types observed in both locations is similar to the findings of Nigeria by [2] in southwestern part of Nigeria, but contrary to the findings of [3] and [26] who reported that E. saccharina and $S$. calamistis as the most important stemborers on maize in the forest zone of eastern Nigeria, the forest/savanna transition zone of south western Nigeria. Though not investigated, the nature of the vascular tissues of popcorn may have contributed to the relatively higher preference of $B$. fusca for it. The absence of $A$. ignefusalis in flint corn in the Guinea Savanna zone is yet to be determined whether or not it is a case of escape of infestation. But its absence in the Rainforest zone maybe due to location effects and absence of millet in neighboring plots. A. ignefusalis is a millet stem borer, but could infest other cereals [29]. In addition, $C$. partellus was absent in larval population recovered from both 
location. But [27] reported that factors such as temperature, rainfall and humidity influences the distributions of $B$. fusca and $C$. partellus, with temperature being the most important. He indicated that $C$. partellus was found in warmer regions and $B$. fusca in cooler areas. This generalization may be the possible reason for the absence of $C$. partellus in cooler environment of the Rainforest zone of Nigeria.

The significant reduction in borer population by single dose application of carbofuran at the rate of $1.5 \mathrm{~kg}$ a.i.ha ${ }^{-1}$ further confirms the effectiveness of the chemical in the control of stem borers. Similar results have been reported by $[6,4]$. In spite of health and environmental risks associated with the use of chemicals for pest control, they continues to play the important role of minimizing crop loss associated with increase in insect pest population in farmer's field. It is important to note that carbofuran is a systemic insecticide which is effective even after the larvae penetrate into the stem [4]. Their use in late season maize could leave residues in the grains; hence, non-systemic alternative is suggested.

The three maize types used in the experiment were susceptible to stem borer infestation and damage. The high population of larvae observed in their stems may be the reason for high level of borer damage observed in the study. This agrees an earlier observation by [9] who found significant increase in infestation and damage as well as yield reduction with increase larval population.

The higher grain yield observed in flint corn compared with either pop or sweet corn may be due to the lower damage observed in the maize type in both locations as well as differences in grain morphometrics and weight. Noteworthy, infested plants also yielded cobs filled with grains in spite of borer tunneling activities which resulted in stem lodging and cavities in the stems of the three maize types. This result was not unexpected because maize has scattered vascular bundle typical of a monocotyledonous plant, which enables the plant to translocate nutrients and water through undamaged tissues to the yield bearing $\operatorname{sink}(\mathrm{s})$ without significant reduction in yield. In addition, adequate rainfall as well as the use of fertilizers has been reported to exert significant influence on maize yield and stem borer damage [24, 21].

The no significant location $\times$ carbofuran $\times$ maize type and location $\times$ maize type interaction effect detected for all parameters show that infestation, damage and yield were not significantly affected by the combinations of these factors. However, the significantly higher damage values observed in carbofuran-untreated plots in the Rainforest zone compared with the treated plots and treated and untreated plots in the Southern Guinea Savanna zone reveals the impact of location and borer control with carbofuran on bored stem, larval population per plant and number of exit holes in the maize types. Generally, herbivore activities can vary with habitat type depending on the prevailing conditions in a given ecosystem [1, 20]. Furthermore, the combination of borer control with carbofuran and maize types had significant effect on bored stem, bored ear, number of exit holes per plant, number of stem borer cavities per plant, number of damaged seeds per plant and number of filled cobs per plant. This may also have resulted from differences in maize type's ability to absorb carbofuran from the soil.

\section{Conclusion}

The study was carried out to assess the effect of three maize types (flint, pop and sweet corn) and borer control with carbofuran on the severity of maize stem borer infestation and damage in Southern Guinea Savanna and Rainforest agro-ecological zones of Nigeria. The results revealed that yield loss due to stem borer infestation and damage could be severe if the pest is not managed during the late maize cropping season (August to November) in both locations. Furthermore, the lower infestation and damage levels in flint corn compared with pop and sweet corn in carbofuran-treated and untreated plot in the Southern Guinea Savanna and Rainforest zone of Nigeria, suggests that flint corn may be more productive when grown by resource-poor farmers in both locations. However, infestation and damage by stem borer can be suppressed with single dose soil application of carbofuran at the rate of $1.5 \mathrm{~kg}$ a.i.ha ${ }^{-1}$. Further studies still should be conducted to assess the extent of damage caused by individual borer species and their implications on the yield of each maize type in controlled environment. This will provide additional empirical evidence of the economic status of the pest.

\section{Acknowledgements}

The authors are grateful to Professors O. E. Ogunwolu and M. O. Adeyemo for their invaluable inputs during the planning and execution of the field work at the Makurdi, Nigeria.

\section{References}

[1] Altieri, M. A. and Nicholls C. I. 2004. Biodiversity and pest management in agroecosystems, $2^{\text {nd }}$ editors. The Haworth Press Inc. URL: http://www.scribd.com/doc/12591031/Biodiversity-and-PestManagement-in-Agroecosystems

[2] Balogun, O. S. and Tanimola, O. S. 2001. Preliminary studies on the occurrence of stem borer and incidence of stalk rot under varying plant population densities in maize. Journal of Agricultural Research and Development 1: 67-73. http://dx.doi.org/10.4314/jard.v1i1.42191

[3] Bosque-pérez N A. and Mareck J. H. 1990. Distribution and composition of lepidopterous maize borers in southern Nigeria. Bulletin of Entomological Research 80: 363-368. DOI: http://dx.doi.org/10.1017/S0007485300050604

[4] Bosque-pérez, N. A. 1995. Major insect pests of maize in Africa: biology and control. IITA Research Guide 30. Second edition. Training Program, International Institute of Tropical Agriculture (IITA), Ibadan, Nigeria. 30 p. URL: http://www.fao.org/sd/erp/toolkit/books/majorinsectpestsofmai ze.doc 
[5] Bosque-perez, N. A. and Schulthess, F. 1998. Maize: West and Central Africa. In Polaszek, (ed.). African Cereal Stem borers: Economic Importance, Taxonomy, Natural Enemies and Control. CAB International, Wallingford, UK, pp. 11-24. URL: http://www.cabi.org/bookshop/book/2399

[6] Egwuatu, R. I. and Ita, C. B. 1982. Some effects of single and split application of Carbofuran on the incidence of damage by Locris maculata, Busseola fusca and Sesamia calamistis on maize. Tropical Pest Management: 28:227-283. DOI: $10.1080 / 09670878209370721$

[7] FAOSTAT 2013. Maize yield estimate for Nigeria. FAO Statistics Division. Retrieved 10:00 GMT 18 April, 2013.

[8] Genstat Discovery Edition 4 (2011). VSN International Ltd., Rothamsted Experimental Station.

[9] Girling, D. J. 1980. Eldana saccharina as a crop pest in Ghana. Tropical Pest Management. 26: 156-156. DOI: http://dx.doi.org/10.1080/09670878009414386

[10] Hammond, R. B. and Pedigo, L. P. 1982. Determination of yield-loss relationships for soyabeans defoliators by using simulated insect-defoliation techniques. Journal of Economic Entomology 75: 102-107. DOI: http://www.ingentaconnect.com/content/esa/jee/1982/0000007 5/00000001/art00026

[11] Harris, K. M. 1962. Lepidopterous stem borers of cereals in Nigeria. Bulletin of Entomological Research. 53:139-171. DOI: http://dx.doi.org/10.1017/S0007485300048021

[12] Harris K. M. 1990. Bioecology of Chilo species. Insect Science and its Application 11: 467-477. DOI: http://dx.doi.org/10.1017/S1742758400021044

[13] Holloway J. D. 1998. Noctuidae: Introduction. In: Polaszek A, editor. African cereal stem borers: economic importance, taxonomy, natural enemies and control, pp. 79-86. CTA/CABI International. URL: http://www.cabi.org/bookshop/book/2399

[14] Iken J. E and N. A. Amusa 2010. Consumer acceptability of seventeen popcorn maize (Zea mays L.) varieties in Nigeria African Journal of Agricultural Research Vol. 5(5), 405-407. URL: http://www.academicjournals.org/journal/AJAR/articleabstract/2B5B9D627885

[15] Iken, J. E. and Amusa, N. A. 2004. Maize Research and Production in Nigeria. African Journal of Biotechnology. 3 (6): 306. DOI: 10.5897/AJB2004.000-2056

[16] IITA (International Institute of Tropical Agriculture) 2014. Maize. URL: http://www.iita.org/maize $22^{\text {nd }}$ June, 2014

[17] Kfir, R. 2013. Maize Stem Borers in Africa: Ecology and Manage-ment. Encyclopedia of Pest Management. Taylor and Francis: New York, Published online $\mathrm{http}: / /$ www.tandfonline.com/doi/abs/10.1081/E-EPM120048597

[18] Kfir, R. 2002. Increase in cereal; stem borer populations through partial elimination of natural enemies. Entomologia Experimentalis et Applicata. 104: 299-306. http://dx.doi.org/10.1046/j.1570-7458.2002.01016.x
[19] Maes K. 1998. Pyraloidea: Crambidae, Pyralidae. pp. 87-98 In. Polaszek A. 1998. African Cereal Stem Borers: Economic Importance, Taxonomy, Natural Enemies and Control. Wallingford, UK: CABI. 530 pp. DOI: http://www.cabi.org/bookshop/book/2399

[20] Mailafiya D.M., Le Ru B.P., Kairu E. W., Dupas S, Calatayud P.A. 2011. Parasitism of lepidopterous stem borers in cultivated and natural habitats. Journal of Insect Science 11:15. http://dx.doi.org/10.1673/031.011.0115

[21] Moyal, P. 1995. Borer infestation and damage in relation to maize stand density and water stress in the Ivory Coast. International Journal of Pest Management. 41:114-121. http://dx.doi.org/10.1080/09670879509371934

[22] NRI (Natural Resource Institute) 1996. A Guide to Insect Pests of Nigerian Crops: Identification, Biology and Control. Federal Ministry of Agriculture and Natural Resources and the Oversea Development Administration. UK.

[23] Okrikata, E., and C. Anaso 2008. Influence of some inert diluents of neem kernel powder on protection of sorghum against pink stalk borer (Sesemia Calamistis, Homps) in Nigerian Sudan Savanna. Journal of Plant Protection Research. 48 (2):161-168. DOI: 10.2478/v10045-008-0019-4.

[24] Polaszek, A. 1998. African Cereal Stem borers: Economic Importance, Taxonomy, Natural Enemies and Control. CAB international, Wallingford, UK, 345p. DOI: http://www.cabi.org/bookshop/book/2399

[25] Schulthess, F., Bosque-perez, N.A. and Gonuou, S. 1991. Sampling lepidopterous pests on maize in West Africa. Bulletin of Entomological Research. 8: 297-301. http://dx.doi.org/10.1017/S0007485300033575

[26] Schulthess, F., Bosque-Pe'rez, N.A., Chabi-Olaye, A., Gounou, S., Ndemah, R. \& Goergen, G. 1997. Exchanging natural enemies species of lepidopterous cereal stemborers between African regions. Insect Science and its Application, $17,97-108$

[27] Sithole, S. Z. 1987. The effect of date of planting on shootfly and stem borer infestations on sorghum, pp. 174 - 183. In Proceedings of the Third Regional Workshop on Sorghum and Millets for Southern Africa, 6 - 10 October 1986, Lusaka, Zambia, ICRISAT, Patancheru.

[28] Smith, J. W., Wiedenmann R. N., Overholt W. A. 1993. Parasites of lepidopteran stem borers of tropical gramineous plants. ICIPE Science Press. URL: http://www.abebooks.com/Parasites-LepidopteranStemborers-Tropical-Gramineous-Plants/10814893292/bd

[29] Youm, O., Harris, K. M., and Nwanze, K. F. 1996. Coniesta ignefusalis (Hompson), the millet stem borer: a handbook of information. (In En. Summaries in En, Fr, Es.) Information Bulletin no. 46. Patancheru 502 324, Andhra Pradesh, India: International Crops Research Institute for the Semi-Arid Tropics. 60 pp. URL: http://trove.nla.gov.au/version/26607464 